\title{
Difference in Effectiveness of Various Gibberellins on Shoot Elongation and Flower Formation in Pharbitis nil Chois.
}

\author{
Yukiyoshi OGawa \\ Faculty of Agriculture, Mie University, Tsu 514-22, Mie, Japan
}

\begin{abstract}
Summary
Various $C_{20}$-gibberellins, $A_{18}, A_{38}, A_{23}, A_{28}$ and $A_{27}$, and various $C_{19}$-gibberellins, $A_{1}, A_{2}, A_{3}, A_{4}, A_{5}, A_{7}, A_{8}, A_{9}, A_{20}, A_{21}$ and $A_{22}$ were applied to the cotyledonary plumule of Pharbitis nil Chois., cv. Kidachi which was subjected subsequently to an inductive dark period of relatively short duration. Their promotive activities were examined in shoot elongation as well as flower formation. The order in the promoting activity of these $\mathrm{C}_{20}$-gibberellins except $\mathrm{GA}_{27}$ and $\mathrm{GA}_{3}$ at $0.05 \mu \mathrm{g}$ dosage on both the shoot elongation and the flower formation was observed as follows : $A_{3} \gg A_{38} \geqq A_{23} \geqq$ $A_{18} \gg A_{28}=$ water control. At $0.5 \mu \mathrm{g}$ dosage the same order in the shoot elongation was observed, but the order in the activity on the flower formation was observed as follows : $A_{38}>A_{3}=A_{23}=A_{18} \gg A_{28}=$ water control. The order in the promotive activity of various $\mathrm{C}_{19}$-gibberellins and $\mathrm{GA}_{27}$ at $0.05 \mu \mathrm{g}$ dosage on both of the responses was observed as follows: $A_{3}>A_{1}=A_{7}>A_{5}>A_{2}=A_{4} \geqq A_{20}>A_{22}>A_{9} \geqq A_{8}=A_{21}=$ $\mathrm{A}_{27}=$ water control. At $0.5 \mu \mathrm{g}$ dosage the same order in growth activity on the shoot elongation was also observed, but the order in the activity on the flower formation was observed as follows: $A_{2}=A_{4}=A_{5}>A_{1}=A_{7} \geqq A_{3}=A_{20}>A_{21}>A_{9}=A_{8}=$ $A_{27}=$ water control. The gibberellins which have growth promotive activity were always active in flowering, and the opposite was also true. The discrepancy in the order of highly active gibberellins at high dosage between the growth promotive activity and the flower promotive activity may be due to the fact that flower promotive activity at high dosage somewhat decreases, irrespective of highly promotive activity in shoot elongation.
\end{abstract}

\section{Introduction}

The extracts obtained from the seeds of $\mathrm{Lu}$ pinus, Pharbitis or Phaseolus, which were applied to cotyledonary plumule of Pharbitis plants preceding an inductive dark period, have promoted flower formation as well as shoot elongation $(10,12)$. Similar promotion has been obtained also by the application of $\mathrm{GA}_{3}(11,13)$. Therefore, the promotive activity of the seed extract is possibly caused by some gibberellins present in the extract. On the other hand, $\mathrm{C}_{20}$-gibberellins, $\mathrm{A}_{18}, \mathrm{~A}_{23}$ and $\mathrm{A}_{28}$ were isolated from the extract of Lupinus seeds $(2,4,5,14)$ and the same carbon gibberellin, $\mathrm{A}_{38}$ from the extract of Phaseolus seeds (3). The various $\mathrm{C}_{19}$-gibberellins, $\mathrm{A}_{1}, \mathrm{~A}_{2}, \mathrm{~A}_{3}$, $\mathrm{A}_{4}, \mathrm{~A}_{5}, \mathrm{~A}_{7}, \mathrm{~A}_{8}, \mathrm{~A}_{9}, \mathrm{~A}_{20}, \mathrm{~A}_{21}$ and $\mathrm{A}_{22}$, and $\mathrm{C}_{20^{-}}$ gibberellin, $A_{27}$ have been isolated from the seed extract of Pharbitis, Phaseolus and others

Received for publication April 12, 1976
$(3,6,7,8,9,19)$. The present paper will report comparative effectiveness of these gibberellins on both the shoot elongation and the flower formation in Pharbitis nil Chois., which was exposed to an inductive dark period of relatively short duration, preceded by the external application of the gibberellins.

\section{Materials and Methods}

As the experimental plant, the seedling of Pharbitis nil Chois., cv. Kidachi was used. The seeds which treated with conc. $\mathrm{H}_{2} \mathrm{SO}_{4}$ for 30 minutes were washed throughly in running water for one day, and spread on moistened sand in a petri dish. Next days, the seeds which begin to germinate were sown in six parallel lines in $35 \times 45 \mathrm{~cm}$ wooden box filled with garden soil. Each of the lines is consisted of 10 seeds. They were placed under sun light during the day and a fluorescent lamp of 2000 lux intensity at plant level during the night in the glasshouse controlled at 
$28 \pm 2^{\circ} \mathrm{C}$. Two days after sowing, the seedling emerged from the soil and expanded the cotyledon, and five days after sowing the aqueous solution of gibberellin was dropped onto the cotyledonary plumule of plant by means of glass capirally, line to line. First, $\mathrm{C}_{20}$-gibberellins, $\mathrm{A}_{18}, \mathrm{~A}_{38}, \mathrm{~A}_{23}$ and $\mathrm{A}_{28}$, which had been isolated from Lupinus seeds with exception of $\mathrm{GA}_{38}$, were tested in their activity by comparing with the activity of $\mathrm{GA}_{3}$. Second, $\mathrm{C}_{19}-$ gibberellins, $A_{1}, A_{2}, A_{3}, A_{4}, A_{5}, A_{7}, A_{8}, A_{9}, A_{20}$, $A_{21}$ and $A_{22}$ and $G_{27}$, most of which had been isolated from Pharbitis seeds, were tested. Each plant was treated with about $0.05 \mathrm{ml}$ of test solution. Many boxes with the plants were used so that 16 to 20 plants receive a test solution. Thereafter, the plants were subjected to an inductive dark period of 11 hour duration at $26 \pm 1^{\circ} \mathrm{C}$ and then they were transferred again to the same glasshouse. About two or three weeks after the dark period the plants were harvested and the shoot length was measured in $\mathrm{mm}$ by a ruler and the flower bud on the stem was examined under binocular microscope. The formation of flower bud was indicated as the number of flower bud per one plant.

\section{Results}

The activities of $\mathrm{A}_{18}, \mathrm{~A}_{38}, \mathrm{~A}_{23}, \mathrm{~A}_{28}$ and $\mathrm{A}_{3}$ on both shoot elongation and flower formation are shown in Figs. 1 and 2. All the gibberellins except $A_{28}$ promoted strongly shoot elongation as well as flower formation. The order in the promotive activity at $0.05 \mu \mathrm{g}$ dosage was the same on both of the responses and was shown as follows : $A_{3} \gg A_{38} \geqq A_{23} \geqq A_{18} \gg A_{28}=$ water control. At $0.5 \mu \mathrm{g}$ dosage these gibberellins except $\mathrm{GA}_{28}$ promoted much more shoot elongation as well as flower formation. The order in the promotive activity on the shoot elongation was almost the same as that mentioned above, but the order in the activity on the flower formation was observed as follows: $A_{38}$ $>A_{3}=A_{23}=A_{18} \gg A_{28}=$ water control. Thus, the order of the active gibberellins on the flower formation was different from the order on the shoot elongation.

The activities of $A_{1}, A_{2}, A_{3}, A_{4}, A_{5}, A_{7}, A_{8}, A_{9}$, $A_{20}, A_{21}, A_{22}$ and $A_{27}$ on shoot elongation and flower formation are shown in Figs. 3 and 4.
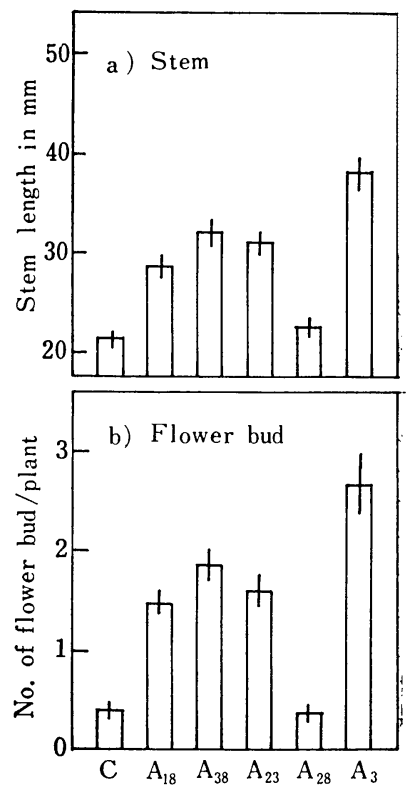

Fig.1. Effects of $\mathrm{C}_{20}$-gibberellins, $\mathrm{A}_{18}, \mathrm{~A}_{38}, \mathrm{~A}_{23}$ and" $A_{28}$, and $G_{3}$ at $0.05 \mu \mathrm{g}$ dosage on shoot elongation and flower formation in Pharbitis nil Chois. Each bar represents the mean of 16-20 plants. Standard error is given by vertical line.



Fig.2. Effects of $\mathrm{C}_{20}$-gibberellins, $\mathrm{A}_{18}, \mathrm{~A}_{38}, \mathrm{~A}_{23}$ and" $\mathrm{A}_{28}$, and $\mathrm{GA}_{3}$ at $0.5 \mu \mathrm{g}$ dosage on shoot elongation and flower formation in Pharbitis nil Chois. Each bar represents the mean of $16-20$. plants. Standard error is given by vertical line. 

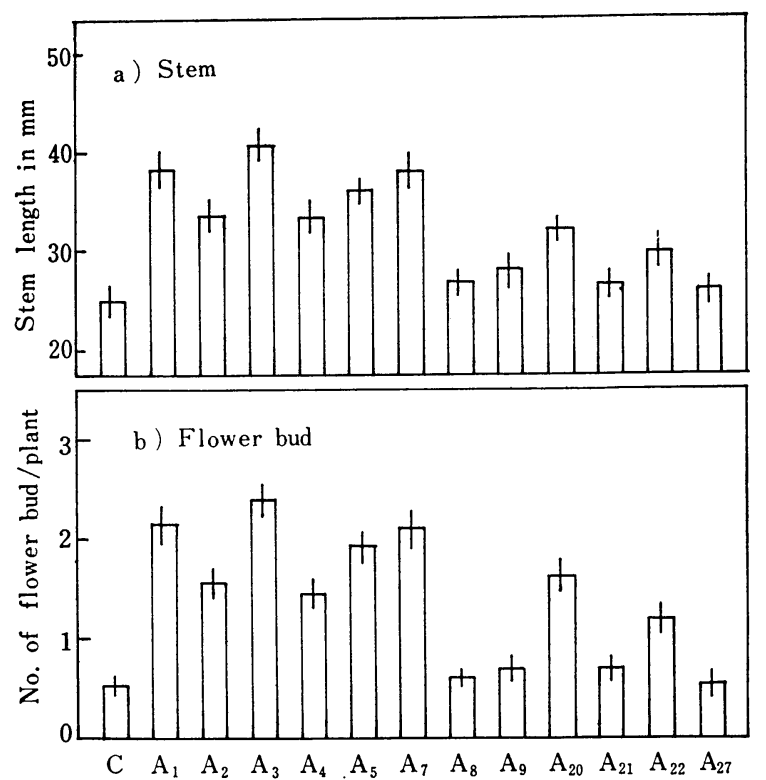

Fig.3. Effects of $\mathrm{C}_{19}$-gibberellins, $\mathrm{A}_{1}, \mathrm{~A}_{2}, \mathrm{~A}_{3}, \mathrm{~A}_{4}, \mathrm{~A}_{5}, \mathrm{~A}_{7}$, $A_{8}, A_{9}, A_{20}, A_{21}$ and $A_{22}$, and $G_{27}$ at $0.05 \mu \mathrm{g}$ dosage on shoot elongation and flower formation in Pharbitis nil Chois. Each bar represents the mean of $16-20$ plants. Standard error is given by vertical line.
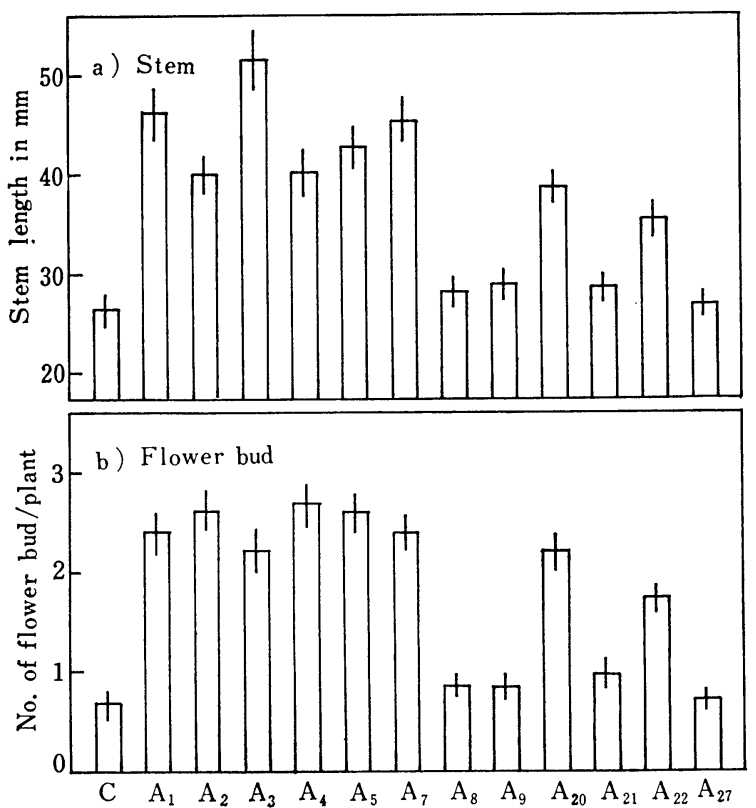

Fig.4. Effects of $C_{19^{-}}$gibberellins, $A_{1}, A_{2}, A_{3}, A_{4}, A_{5}, A_{7}$, $A_{8}, A_{9}, A_{20}, A_{21}$ and $A_{22}$, and $G_{27}$ at $0.5 \mu$ d dosage on shoot elongation and flower formation in Pharbitis nil Chois. Each bar represents the mean of 16-20 plants. Standard error is given by vertical line.

$\mathrm{GA}_{8}, \mathrm{GA}_{9}, \mathrm{GA}_{21}$ and $\mathrm{GA}_{27}$ were slightly active or almost inactive in both shoot elongation and flower formation. The order in gibberellin activity at $0.05 \mu \mathrm{g}$ dosage was much the same in both of the responses, and was. shown as follows: $A_{3}>A_{1}=A_{7}>A_{5}>A_{2}=A_{4}$ $\geqq A_{20}>A_{22}>A_{9} \geqq A_{8}=A_{21}=A_{27}=$ water control. At $0.5 \mu \mathrm{g}$ dosage, the active gibberellins promoted much more shoot elongation. as well as flower formation. The same order was observed also on the shoot elongation at $0.5 \mu \mathrm{g}$ dosage. However, the order of the active gibberellins was differently observed. in flower formation, that is, $A_{2}=A_{4}=A_{5}>$ $\mathrm{A}_{1}=\mathrm{A}_{7} \geqq \mathrm{~A}_{3}=\mathrm{A}_{20}>\mathrm{A}_{21}>\mathrm{A}_{9}=\mathrm{A}_{8}=\mathrm{A}_{27}$ = water control.

The activity of $\mathrm{GA}_{3}$ at various dosages on flower formation was examined by comparing with the activity on shoot elongation. The results are shown in Fig. 5. Even a small dosage as $0.005 \mu \mathrm{g}$ was effective on the flower formation, although no significant

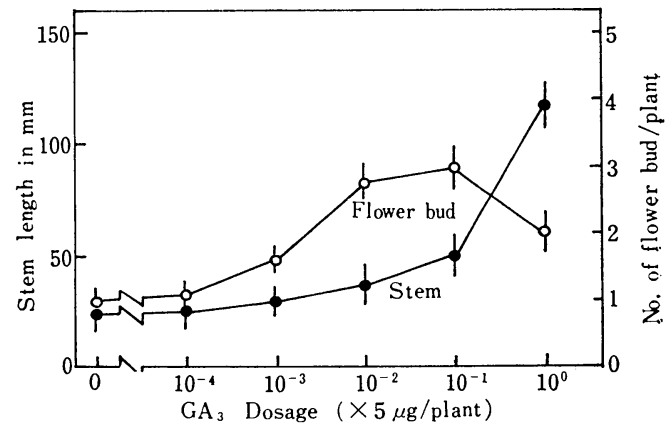

Fig.5. Effects of $\mathrm{GA}_{3}$ at various dosages on shoot elongation and flower formation in Pharbitis nil Chois. Each point represents the mean of $16-20$ plants. Standard error is given by vertical line.

promotion was obtained in shoot elongation. The increase of dosage brought about higher promotion in both shoot elongation and flower formation. However, the extent of the promotive activity in flowering caused by $0.5 \mu \mathrm{g}$ dosage decreased to some degree, and promotion in flowering became much less at $5 \mu \mathrm{g}$ dosage, even though much higher promotion in growth was obtained.

\section{Discussion}

It has been reported previously that the seed extract from Lupinus, Phaseolus or Pharbitis brought about promotion in flower formation as well as shoot elongation in Phar- 
bitis nil Chois. $(10,12)$. On the other hand, the other previous papers have shown that the extract from Lupinus seed contains $\mathrm{GA}_{18}$, $\mathrm{GA}_{23}$ and $\mathrm{GA}_{28}$, and probably does not contain other gibberellin $(2,4,5,14)$. The extract from Phaseolus seed has been found to contain $\mathrm{GA}_{38}$ besides some $\mathrm{C}_{19}$-gibberellins (3). Thus, it is concluded that the Lupinus extract is promotive in flowering by the activity of $\mathrm{GA}_{18}$ and $\mathrm{GA}_{23}$, and the Phaseolus extract is promotive by the activity of $\mathrm{GA}_{38}$ and some other active gibberellins. These $\mathrm{C}_{20}$-gibberellins are assumed to be precursors of $\mathrm{C}_{19}$-gibberellins, $A_{1}$ and $A_{3}$ which are very highly active (1). However, it is difficult to establish whether these $\mathrm{C}_{20}$-gibberellins are physiologically active per $s e$ in the plumule of Pharbitis, or whether their promotive activities occur after conversion to $\mathrm{GA}_{1}$ and $\mathrm{GA}_{3}$. In the present stu$\mathrm{dy}, \mathrm{GA}_{38}$ is somewhat more active than $\mathrm{GA}_{23}$ irrespective of the idea that $\mathrm{GA}_{38}$ is the precursor of $\mathrm{GA}_{23}$, suggesting that $\mathrm{GA}_{38}$ is active per se in Pharbitis. Incidentally, the other experiments carried out with barley endosperm support the former viewpoint that $\mathrm{GA}_{38}$ and $\mathrm{GA}_{23}$ are active per se $(15,17)$. In Pharbitis seed the occurrence of gibberellins, $A_{3}$, $A_{5}, A_{8}, A_{20}, A_{26}, A_{27}$ and $A_{29}$, and that of their glucosides except $A_{5}$ has been reported $(6,19$, 20,21). Although $\mathrm{GA}_{26}$ and $\mathrm{GA}_{29}$ have not been examined in the present study, they are not thought to have relation to the response of Pharbitis, judging from their very weak activities in other bioassays (21). In the other report, it is also noted that $\mathrm{GA}_{3}$-glucoside is also very weakly promotive in flower formation and almost inactive in shoot elongation of Pharbitis (16). Thus, the flower promotive activity of the extract from Pharbitis seed is assumed to be due mainly to $\mathrm{GA}_{3}, \mathrm{GA}_{5}$ and $\mathrm{GA}_{20}$, and rarely to their glucosides except $\mathrm{GA}_{5}$. Speaking generally with Pharbitis seedling, the gibberellins which have growth promotive activity are always active in flowering, and the opposite is also true. The promotion in mitotic activity of $\mathrm{GA}_{3}$ in the apical meristem of Pharbitis seedling has been reported by OKuda (18). Therefore, the flower promotive activity of varioùs gibberellins must also depend upon their mitotic activities in the stem apex. It has been noted that the order in grow- th promotive activity caused by highly active gibberellins at high dosage is not always the same as the order in flower promotive activity. The difference in both of the orders could result in the fact that at high dosage the flower promotive activity decreases to low irrespective of much highly promotive activity in shoot elongation. It might be suggestion that the difference is related to some different function of gibberellin between the flower formation and the shoot elongation.

\section{Acknowledgement}

The author wishes to thank to Prof. K. Koshimizu, Kyoto University, Prof. J. MacMrLlan, University of Bristol and Prof. N. TAKAHAShI, University of Tokyo, for supply of gibberellins used in the present experiments, and to Prof. I. Ohta, the chief of the Institute for Experimental Farming of Mie University, for his continuous encouragement.

\section{Literature cited}

1. DURELY, R. C., I. D. RAILTON and R. P. PhaRis. 1973. The metabolism of gibberellin $A_{1}$ and gibberellin $\mathrm{A}_{14}$ in seedlings of dwarf Pisum sativum. Plant Growth Substances 1973, 285-293, Hirokawa Publishing Co., Tokyo, 1974.

2. FUkUi, H.,K. KoshimizU and T. Mitsui. 1971. Gibberellin $A_{28}$ in the fruits of Lupinus luteus. Phytochem. $10: 671-673$.

3. Hiraga. K., T. Yokota, N. MUROFUShi and N. TAKAHASHI. 1973. Plant growth regulators in immature and mature seeds of Phaseolus vulgaris. Plant Growth Substances 1973, 78-85, Hirokawa Publishing Co., Tokyo, 1974.

4. Koshimizu, K., H. FukUi, T. Kusaki, Y. OGAWA and T. Mitsur. 1968. Isolation and structure of gibberellin $A_{18}$ from immature seeds of Lupinus luteus. Agr. Biol. Chem. $32: 1135-1140$.

$5 . \quad-$, M. INUI, — and 1968. Gibberellin $A_{23}$ in immature seeds of Lupinus luteus. Tetrahedron letters, $9: 1143-1147$.

6. Murofusiin, N., N. Takahashi, T. Yokota and S. TAMURA. 1968. Gibberellins in immature seeds of Pharbitis nil. Part I. Isolation and structure of a novel gibberellin. Gibberellin $A_{20}$. Agr. Biol. Chem. $32: 1239-1245$.

7. Macmillan, J., J. C. Seaton and P. J. Suter. 1960. Plant hormones-1. Isolation of gibbe- 
rellin $A_{1}$ and gibberellin $A_{8}$ from Phaseolus multiflorus. Tetrahedron, $11: 60-66$.

8.

hormones-11. Isolation and structure of gibberellin $A_{6}$ and gibberellin $A_{8}$. Tetrahedron, $18: 349-355$.

9. 1968. Direct identification of gibberellins in plant extracts by gas chromatography-mass spectrometry. Biochem. Physiol. Plant Growth Substances, 101-107, The Runge Press Ltd., Ottawa, 1968.

10. OGAWA, Y. und S. IMAMURA. 1958. Über die fördernde Wirkung von Samendiffusate auf die Blütenbildung einer Kurztagpflanzen, Pharbitis nil Chois., Proc. Jap. Acad., 34 : $631-632$.

11. _— und 1958. Über die fördernde Wirkung von Gibberellin auf die Blütenbildung einer Kurztagpflanzen, Pharbitis nil Chois. Proc. Jap. Acad., 34 : 633634 .

12. und 1960. Über die Wirkung der Pflanzendiffusate auf die Streckung des Sprosses und die Blütenbildung von $P h$ arbitis nil Chois. Bot. Mag. Tokyo, 73 : 125 -132 .

13. 1960. Über die Wirkung des Gibberellins auf die Blütenbildung von Pharbitis nil Chois. Plant and Cell Physiol., 2 : 311329.

14. 1966. Properties of gibberellin-like substances in the seeds of Lupinus luteus. Bot. Mag. Tokyo, $79:$ 197-199.
15. and K. KoshimizU. 1973. Activities of 3,13 -dihydroxy $\mathrm{C}_{20}$-gibberellins in endosperm tests of cereals. Plant Growth Substances 1973, 267-274, Hirokawa Publishing Co. Tokyo, 1974.

16. and N. TAKAHASHI. 1974. Comparative biological effectiveness of gibberellin $A_{3}$-glucoside and gibberellin $A_{3}$. Bull. Fac. Agr. Mie Univ., 46 : 261-267.

17. 1977. Physiological activity of $\mathrm{C}_{20^{-}}$ gibberellins, $A_{38}$ and $A_{23}$ per se in barley and oat endosperms. Bull. Fac. Agr. Mie Univ., $52: 23-31$.

18. OKUDA, M. 1964. Physiological observation of the gibberellin effects on the development and growth of plants. Contri. Biol. Lab. Kyoto Univ., $18: 1-36$.

19. YoKota, T., N. MUROFUSHI, N. TAKAHASHI and S. TAMURA. 1971. Gibberellins in immature seeds of Pharbitis nil. Part II. Isolation and structures of novel gibberellins. Gibberellins $A_{26}$ and $A_{27}$. Agr. Biol. Chem. 35 : $573-582$.

20.

1971. Gibberellins in immature seeds of Pharbitis nil. Part III. Isolation and structures of gibberellin-glucosides. Agr. Biol. Chem. $35: 583-595$.

21.

MI. 1971. Biological activities of gibberellins and their glucosides in Pharbitis nil. Phytochem., $10: 2943-2949$.

\section{アサガオの茎の伸長ならびに花芽形成に及ぼす各種の \\ ジベレリンの作用の比較

$$
\begin{array}{cl}
\text { 小 } & \text { 幸 持 } \\
\text { (三重大学 } & \text { 農学部) }
\end{array}
$$

\footnotetext{
摘要

誘導暗期の直前に，短日植物，アサガオの幼芽にアサ ガオルーピンあるいはインゲンなぞの種子のアセトン 抽出物を与觉ると, 対照区に比して茎の伸長ならびに花 芽の形成が促進される．同じょうな促進作用がジベレリ ン $\mathrm{A}_{3}$ を与えた場合でも得られることが知られている. 本報文では，上記の各種の種子から分離された炭素-20 個のジベレリン $\left(\mathrm{C}_{20}{ }^{-}\right) \mathrm{A}_{18}, \mathrm{~A}_{38}, \mathrm{~A}_{23}, \mathrm{~A}_{28}$ と $\mathrm{A}_{27}$, また 炭素-19 個のジベレリン $\left(C_{19}{ }^{-}\right) A_{1}, A_{2}, A_{3}, A_{4}, A_{5}, A_{7}$, $A_{8}, A_{9}, A_{20}, A_{21}$ と $A_{22}$ の作用を，アサガオの茎の伸長

ならびに花芽形成に执いて比較調査した。

アサガオの園芸品種， キダチをガラス室内で $(28 \pm 2$ $\left.{ }^{\circ} \mathrm{C}\right)$, 昼間は太陽光, 夜間は蛍光灯の連続照明下で育成 し，その幼芽に上記の各種のジベレリン溶液を滴下し， 直ちに 1 回の 11 時間の誘導暗期を与えた.

$0.05 \mu \mathrm{g}$ の供試量の各種 $\mathrm{C}_{20}$-ジベレリンと $\mathrm{GA}_{3}$ の茎

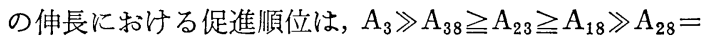
対照区である. 同じ促進順位が花成においてもみられる. $0.5 \mu \mathrm{g}$ の供試量の茎の伸長における促進順位は, $0.05 \mu \mathrm{g}$
} 
の場合とほとんど同じである. 花成においては， $A_{38}>$ $A_{3}=A_{23}=A_{18} \gg A_{28}$ =対照区の順位を示し, 荃の伸長順 位と異なる。

$0.05 \mu \mathrm{g}$ の供試量の各種 $\mathrm{C}_{19}$-ジベレリンと $\mathrm{GA}_{27}$ の 茎の伸長における促進順位は, $A_{3}>A_{1}=A_{7}>A_{5}>A_{2}$ $=A_{4} \geqq A_{20}>A_{22}>A_{9} \geqq A_{8}=A_{21}=A_{27}$ =対照区を示し, 花成においても同じ促進順位である. $0.5 \mu \mathrm{g}$ の供試量 の茥の伸長における促進順位は, $0.05 \mu \mathrm{g}$ の場合とほと んど同じであるが，花成においては， $A_{2}=A_{4}=A_{5}>A_{1}$ $=A_{7} \geqq A_{3}=A_{20}>A_{21}>A_{9}=A_{8}=A_{27}$ =対照区の順位を 示し, 茎の伸長順位と異なる.

各種の供試量の $\mathrm{GA}_{3}$ の作用は, $0.005 \mu \mathrm{g}$ のような 少量では茎の伸長の促進はみられないが, 花成に対し明 らかな促進がみられる。そしてその供試量が増すにつれ
て茎の伸長や花成の促進は両者ともに平行して強まる. しかし $5 \mu \mathrm{g}$ のような多量では茎の伸長は著しく促進さ れるにもかかわらず花成に対する促進は減少する.

アサガオの茎の伸長と花成において各種ジベレリンの 作用を一般的にみて, 茎の伸長を促進するジベレリンは 花芽形成をる促進する. あるいは这に. 花芽形成を促進 するジベレリンは茎の伸長をも促進する. しかし供試量 の多い場合には, 各種ジベレリンの茎の伸長における促 進順位と花芽形成における順位とは異なる.この両者の 相異は, 活性の高いジベレリンは茎の伸長を著しく促進 するにもかかわらず，花芽形成をあまり促進しないため と思われる.これらの事は, ジベレリンの生理的機能が 茎の伸長と花芽形成との間で, その濃度によって, 似て いる場合と異なる場合があることを示唆している. 